\title{
MULTICRITERIAL ANALYSIS OF THE MINING COMPANIES FROM THE ASPECT OF CHANGE MANAGEMENT**
}

The aim of this paper is to evaluate the advantages of the mining companies by the multicriterial analysis in terms of changed management. This approach to the mining companies represents the best practice because there is an increasing number of companies that have been forced to point out their advantages in order to preserve and expand the market positions, profit and successfully change management due to the global changes. This paper analyzes five advantages (alternatives): teamwork, knowledge management, competence, equipment and implementation of an integrated management system (ISM) and four criteria: competitiveness, sustainability, stakeholder satisfaction and positioning. The analysis was carried out using the combined AHP and Electra methods. The presented multicriterial analysis has given the following results: the best alternative is the alternative A5, the implementation of ISM and the most influential criterion is C3, the satisfaction of the stakeholders with a weight coefficient of 0.425 .

Keywords: multicriterial analysis, mining companies, change management

Research Associate, Mining and Metallurgy Institute Bor, Bor, Serbia;

slavica.miletic@irmbor.co.rs

** The research was financed by the Ministry of Education, Science and Technological Development of the Republic of Serbia as a part of the Project TR 33023 Development of Flotation Concentration Technology for Copper and Precious Metals Ore in Order to Achieve Better Technological Results. 


\section{Introduction}

Today, the business success of the mining companies involves considering the business benefits as an ability to understand, adapt, change management and creation of a sustainable business model. Professional management has a task to understand the future of mining companies, their strategic goals: what and how to make changes based on their advantages. Strategic analysis is the first step of the strategic management ${ }^{1}$. Management is a practice of permanent and universal modelling of an organization ${ }^{2}$. The purpose of management is to notice and solve the problems that have arisen leading to their changes and management.

The changes are permanent and they are only secure in modern business. The types of changes according to ${ }^{3}$ are: technological changes; changes of products and services; structural and systematic changes and changes of people. Modern organizations have to be changed constantly so that they can respond to the customers' demands and needs, technological changes and changes of the government measures ${ }^{4}$. The change management, by Certo ${ }^{5}$ and Hayes ${ }^{6}$, is a modification of the organization.

Consequently, the task of the author is to rank the advantages in the mining companies using the multi-criteria analysis, as well as the ability to the change management. Analyzing the advantages of a mining company by implementation the ELECTRA (Elimination and (Et) Choice Translating Reality) method, the professional managers identify, in an easier way, what have to be changed in order to increase the efficiency of realization the products and services ${ }^{7}$. The Electra method belongs to the multi-criteria decision-making methods (MCDM) for decision-making in choosing the most favorable decision among the given alternatives, authored by Bernard Roy ${ }^{8}$.

Using the AHP (Analytical Hierarchy Process) method, an analysis of the criteria impact was made on ranking the mining companies' advantages and their weight coefficients. This method is one of the most famous of the MCDM

$1 \quad$ Sullivan, K., Thomas, S., Rosano, M. ( 2018): Using industrial ecology and strategic management concepts to pursue the Sustainable Development Goals, Journal of Cleaner Production, 174/218, 237-246.

2 Jovanović, P. (1996): Management-Handbook of managemet, FON, Beograd.

3 Daft, R.L. (2001): Organization Theory and Desing, Seventh Edition, South West Publishing, Tomson Learing, Vanderbilt University.

4 Certo, S. (1988): Principles of Modern Managemenat, Allin and Bacon, Bostan. Ibid

$6 \quad$ Hayesu, J. (2002): The Theory and Practice of Change Management, New York.

7 Bogdanović, D. (2016): Upravljanje promenama, Tehnički fakultet u Boru, Univerzitet $\mathrm{u}$ Beogradu.

8 Roy B. (1991): The outranking approach and the foundation of electre methods, Theory Decision 31, 49-73. 
methods ${ }^{9}$. The author of this method is Saaty ${ }^{10}$. In the AHP method, the complex problems of multi-criteria decision-making are parsed in the multidimensional hierarchical structure of criteria and goals ${ }^{11}$.

The methodology of multi-criteria analysis or multi-criteria decisionmaking (MCDM) clearly identifies the main participants in the decision-making process such as the decision makers (DMs), analysts and interested parties, and their role in solving the conflicting problems. The DM defines the defining goals and evaluates the obtained solutions. The analyst is responsible for decision support, constructs a decision model, selects methods, supporting tools, and explains the consequences of such decisions. The interested parties are active participants in the decision-making process for solving problems and making the optimal decisions. A Multicriterial analysis is an area that originated from the operational research - $\mathrm{OP}^{12}$ and focuses its efforts on solving the multiple critical problems ${ }^{13}$. The problems are such complex situations, often contradictory in which they have to be taken into account from a higher point of view ${ }^{14}$. The problem of solving the problem relates to three alternative situations: selection of the best/most desirable variant (selection is problematic), sorting of variances, ice assigning of a predefined class (sorting is problematic) and ranking variants, i.e. ordering from the best to the worst (ranking is a problematic) ${ }^{15},{ }^{16}$.

The applied combined methodology providesagreaterand easieridentification of resolution the conflict problems, the ability to change management, creating a sustainable business model, a more competitive company, increase the company profit and most important, increasing the satisfaction of interested parties due to which the advantages of the mining companies are ranked.

The introduction of extension by the MCDM methods and their interactive use significantly improves the performances of the process in planning and management ${ }^{17}$.

$9 \quad$ Miletić, S., Paunković, Dž., Bogdanović, D. (2016). Evaluacija indikatora održivosti za donošenje odluka u rudarskim kompanijama. Megatrend revija , 13(2)/2016, 83-96. Saaty, T.L. (1980): The Analytical Hierarchy Process, New York: McGraw-Hill.

11 Lee, W.B., Lau, H., Liu, Z.Z., Tam, S. (2001): A fuzzy analytical hierarchy process approach in modular product design, Expert System, 18(1)/2001, 32-42.

12 Hillier, F., \& Lieberman, G. (2001): Introduction to Operations Research, New York: McGraw-Hill.

13 Żak, J., \& Kruszyńskib, M. (2015): Application of AHP and ELECTRE III/IV methods to multiple level, multiple criteria evaluation of urban transportation projects, Transportation Research Procedia, 10/2015 $820-830$.

14 Vincke, P. (1992): Multicriteria Decision - Aid, Chichester: John Wiley \& Sons.

15 Ibid

16 Roy B. (1991): The outranking approach and the foundation of electre methods, Theory Decision 31, 49-73.

17 Kangas J. (2011): Experiences on applying MCDM tools in natural resources management, The 21st International Conference on Multiple. 
The combined MCDM methods have been widely used in solving conflict problems in the mining companies.

The works of a newer date by implementation the combined MCDM methods are: Zavadskas et $a^{18}$, Bogdanović \& Miletić ${ }^{19}$, Zavadskas et $\mathrm{al}^{20}$, Karabasevic et $\mathrm{al}^{21}$, Karabasević et $\mathrm{al}^{22}$, Stanujkić ${ }^{23}$, Stanujkić ${ }^{24}$, Urosevic et $\mathrm{al}^{25}$ and others.

\section{Material and Methods}

In the world of globalization, the mining companies, due to a large number of changes (technological, political, ecological and organizational), operate in increasingly more complex conditions, so that their advantages are indicators of the company's ability to the change management.

The advantages (Alternatives) of the mining company are:

Teamwork (Alternative 1): It involves engagement the necessary competent staff for realization of the production and service process. The effective formation and exploitation of the team gives positive results in the mining companies. In the modern business with constant changes, the teamwork is the most important

18 Zavadskas, E. K., Antucheviciene, J., Saparauskas, J., Turskis, Z. (2013): MCDM methods WASPAS and MULTIMOORA: verification of robustness of methods when assessing alternative solutions, Economic Computation and Economic Cybernetics Studies and Research, 47( 2)/2013, 5-20.

19 Bogdanović, D., \& Miletić, S. (2014):Personnel evaluation and selection by multicriteria decision making method, Journal of Economic Computation and Economic Cybernetics Studies and Research, 48(3)/2014, 179-196.

20 Zavadskas, E. K., Antucheviciene, J., Saparauskas, J., Turskis, Z., (2013): MCDM methods WASPAS and MULTIMOORA: verification of robustness of methods when assessing alternative solutions, Economic Computation and Economic Cybernetics Studies and Research, 47(2)/2013, 5-20.

21 Karabasevic, D., Stanujkic, D., Urosevic, S. \& Maksimovic, M.,(2015): Selection of Candidates in the Mining Industry Based on the Application of the SWARA and the MULTIMOORA Methods, Acta Montanistica Slovaca, 20(2)/2015, 116-124.

22 Karabasevic, D., Zavadskas, E. K., Turskis, Z., Stanujkic, D. (2016): The framework for the selection of personnel based on the SWARA and ARAS methods under uncertainties, Informatica, 27(1)/2016, pp. 49-65.

23 Stanujkić, D. (2015): Extension of the ARAS Method for Decision-Making Problems with Interval-Valued Triangular Fuzzy Numbers, Informatica, 26(2)/2015, 335-355.

24 Stanujkić, D. (2016): An Extension of the Ratio System Approach of Moora Method for Group Decision-Making Based on Interval-Valued Triangular Fuzzy Number, Technological And Economic Development Of Economy, 22(1)/2016, 122-141.

25 Urošević, S., Karabašević, D., Stanujkić; D., Maksimović, M. (2017): An approach to personnel selection in the tourism industry based on the swara and the waspas methods, Economic Computation \& Economic Cybernetics Studies \& Research, 51(1)/2017, 75-88. 
to the mining companies for planning, organizing, implementation, managing and controlling the process.

Knowledge Management (Alternative 2): In the modern business of the mining companies, there is an increasing difficulty in knowledge management. There are many definitions of knowledge management. One of these definitions, according to Sveiby ${ }^{26}$, is "the knowledge management involves identifying and analyzing the available and required resources of knowledge and processes to fulfil the organizational goals". Rapid development and innovations in the mining companies require an efficient application of knowledge, which needs to be managed in an effective and safe way", Hylton ${ }^{27}$. The mining companies must have some knowledge as to stay competitive in the market because the knowledge is in itself a commodity that offers a competitive advantage ${ }^{28}$. Knowledge management is a great advantage of the mining companies. It is important for professional managers to use and direct the knowledge in a proper way. They need to know which intellectual property is owned by the mining companies, and how to manage that property in order to realize a maximum profit ${ }^{29}$.

Staff Competence (Alternative 3): is one of the basic elements of the mining companies that is prescribed in the system management standards. The competence is another one of many changes, a novelty brought by the ISO 9001:2015. Competence is the ability to apply the knowledge to achieve the certain goals of the organization. Personnel training requires the possession of certificates resulting from the requirements of the ISO standards and user requirements. The competent personnel in the mining companies must also have the appropriate knowledge on the product and services process.

Equipment (Alternative 4): The modern sustainable business of professional managers requires the mining companies to be equipped with the innovative eco-technologies. Equipment brings them competition, good positioning, sustainable business, successful change management, as well as the ISO standard compliance and integrated management in order to increase profits and meet the customer requirements.

$26 \quad$ Sveiby, K.E. (1996): What is Knowledge Management? Criteria Decision Making, University of Jyvaskyla, Finland .

27 Hylton, A. (2002): Measuring \& Assessing Knowledge-Value \& the Pivotal Role of the Knowledge Audit, CEO, Hylton Associates.

28 Mazur, M., Spahić, A., Grabar, D., Grd, P.,Sedlbauer, G.,Siroska, K., Pallares Beamonte, E. (2014): Knowledge Management 2.0 for SMEs, km20.eu.

29 Lee, C., Egbu, C., Boyd, D., Xiao, H., \& Chinyo, E. (2005): Knowledge Management for Small Medium Enterprise: Capturing and Communicating Learning and Experiences, 4th Triennial International Conference Rethinking and Revitalizing Construction Safety, Health, Environment and Quality, 808-20. 
Implementation of the Integrated Management System (ISM) (Alternative 5): Today's modern business of the mining companies requires introduction and implementation of the ISO standards (ISO 9001, HACCP, ISO 14001, OHSAS 18001, ISO 22000 and ISO 27001). All these integration systems are an integrated management system. ISO 9001 is an international standard containing the requirements for the quality management system of organizations, which they have to fulfil in order to integrate their business with the internationally recognized standards. The mining companies with integrated ISM operate according to the methodologies; their processes are organized according to the ISO standards; the organizational culture and structure are modelled according to the modern methods, what contributes to the integral management and profit generation. The ISM constantly improves the production processes of the mining companies $^{30},{ }^{31}$.

Criteria are measures or evaluations of the given alternatives and contain the most important characteristics of the hypothesis:

Competitiveness (Criterion 1): The research has shown that competition is the essence of economic science that increases the profit of mining companies. Harold Demsetz thinks that the competition takes the main place in the economy, and it is impossible to imagine it without $\mathrm{it}^{32}$. The mining companies to be more competitive try to produce the products according to the user requirements and requirements of the ISO standard. To be competitive means to satisfy the interested parties, on that way win to win the competition and generate the profit.

Sustainability (Criterion 2): Sustainability of the mining companies implies a harmonized economic, ecological, sociological and cultural development. Sustainability of the mining companies represents the organizational efforts on how to manage the organization in order to meet the demands of interested parties $^{33}$.

Satisfaction of the interested parties (Criterion 3): Interested parties are the integrated groups of people with different interests and responsibilities in

$30 \quad$ Miletić S., Bogdanović, D., Paunković, Dž. (2015): Selection the optimal model of integrated sustainable management system in the mining companies, Journal Mining and Metallurgy Engineering Bor, 2/2015, 181-204.

31 Miletić, S., Bogdanović. D., Milanović, D. (2016): Advantages of implementation the process model for sustainable business operations of mining companies, Journal Mining and Metallurgy Institute Bor, 3/2016, 71-82.

32 Demsetz, H. (1982): Economic, Legal, and Political Dimensions of Competition, NorthHolland, Amsterdam.

33 Miletić, S., Bogdanović, D., Paunković, Dž., Mihajlović, D. (2016): Primena višekriterijumskog odlučivamja u cilju procene održivog poslovanja rudraskih kompanija, Reciklaža i održivi razvoj, 9/2016, 15-20. 
organizations with the same objective named profit. The interested parties in the mining companies develop a sense of dependency and integration to achieve the organizational objectives. Understanding the needs and expectations of the interested parties is under point 4 , the context of an organization, the new requirement of the ISO 9001:2015. Implementation of the Quality Management System (QMS) enables the mining companies to meet the satisfaction of requirements and needs of interested parties.

Positioning (Criterion 4): is a position of the mining company in relation to the competition and perception of the consumers. The positioning determines the place of a company on the market in relation to the competitive products in the consciousness of users. It is important for the mining companies to develop the products that will meet the requirements and needs of the interested parties. The positioning of the company is determined by the low price and high quality of products and services. The position of mining companies on the market determines the competition. Understanding the position of the organization is also the same new clause in the ISO standard ISO 9001:2015.

Employee Resistances (Criterion 5): are created with organizational changes that are a part of today's business in the modern business of the mining companies. They have the negative consequences for employees causing the resistance. Such a working environment gives employees the insecurity and uncertainty in their work $^{34}$. The modern managers are those who manage the change by the best possible way to reduce employee resistance. Employee resistance can reduce the efficiency and productivity in the mining companies.

\section{Analysis of the Problems}

Hypothesis: The benefits of the mining companies contribute to the professional managers the ability of change management.

The authors, in order to determine the weight coefficients of criteria have chosen the AHP method that shows the impact degree of individual criterion on the ranking result. The sum of weight coefficients of criteria must be equal to the unit. If its value is high, it has a greater impact on the ranking result. The scale of comparison is given in Table 1, ranging from 0 to 1 . On the basis of the scale of comparison, a matrix of criterion comparison is formed, shown in Table 2. It was obtained on the basis of an empirical assessment by the decision maker (expert

34 Chauvin, B., Rohmer, O., Spitzenstetter, F., Raffin, D., Schimchowitsch, S., Louvet, E. (2014): Assessment of job stress in factors in context of organizational change, Elsevier Masson SAS. 
team) in order to determine the significance of each criterion for evaluating the advantages of a mining company in order to manage the change management. The expert team consists of 5 managers and relevant experts (mining area).

The results are obtained using the Criterium Decision Plus software, and are shown in Table 3.

Table 1. Scale of comparison the decision making elements

\begin{tabular}{|l|c|}
\hline \multicolumn{2}{|c|}{ Dominations } \\
\hline Description & Rating \\
\hline Equal & 1 \\
\hline Poor domination & 3 \\
\hline Strong domination & 5 \\
\hline Very strong domination & 7 \\
\hline Absolute domination & 9 \\
\hline $2,4,6,8$ are intermediate values & \\
\hline
\end{tabular}

Table 2. Matrix of comparison for criteria

\begin{tabular}{|c|c|c|c|c|c|}
\hline Criteria & $\mathrm{C}_{1}$ & $\mathrm{C}_{2}$ & $\mathrm{C}_{3}$ & $\mathrm{C}_{4}$ & $\mathrm{C}_{5}$ \\
\hline $\mathrm{C}_{1}$ & 1 & 3 & $1 / 2$ & 2 & 5 \\
\hline $\mathrm{C}_{2}$ & & 1 & $1 / 5$ & $1 / 3$ & 1 \\
\hline $\mathrm{C}_{3}$ & & & 1 & 3 & 5 \\
\hline $\mathrm{C}_{4}$ & & & & 1 & 3 \\
\hline $\mathrm{C}_{5}$ & & & & & 1 \\
\hline
\end{tabular}

Table 3. Results obtained by AHP calculations

\begin{tabular}{|c|c|c|c|c|c|}
\hline Criterion & C1 & C2 & C3 & C4 & C5 \\
\hline Weight coefficients of criteria & 0.268 & 0.073 & 0.425 & 0.169 & 0.066 \\
\hline Consistency coefficient & \multicolumn{5}{|c|}{$0.018<0.1$} \\
\hline
\end{tabular}

Based on the implementation of the AHP method, the following results were obtained: The most influential criterion for ranking the advantages of mining companies is the criterion $\mathrm{C} 3$, stakeholder satisfaction; at the second place - criterion $\mathrm{C} 1$, competitiveness; the third place - criterion $\mathrm{C} 4$, positioning; the fourth place - criterion $\mathrm{C} 2$, sustainability, and the fifth place - criterion $\mathrm{C} 5$, employee resistances. Figure 1 shows the hierarchical structure of the AHP method. 
Figure 1. Hierarchical structure

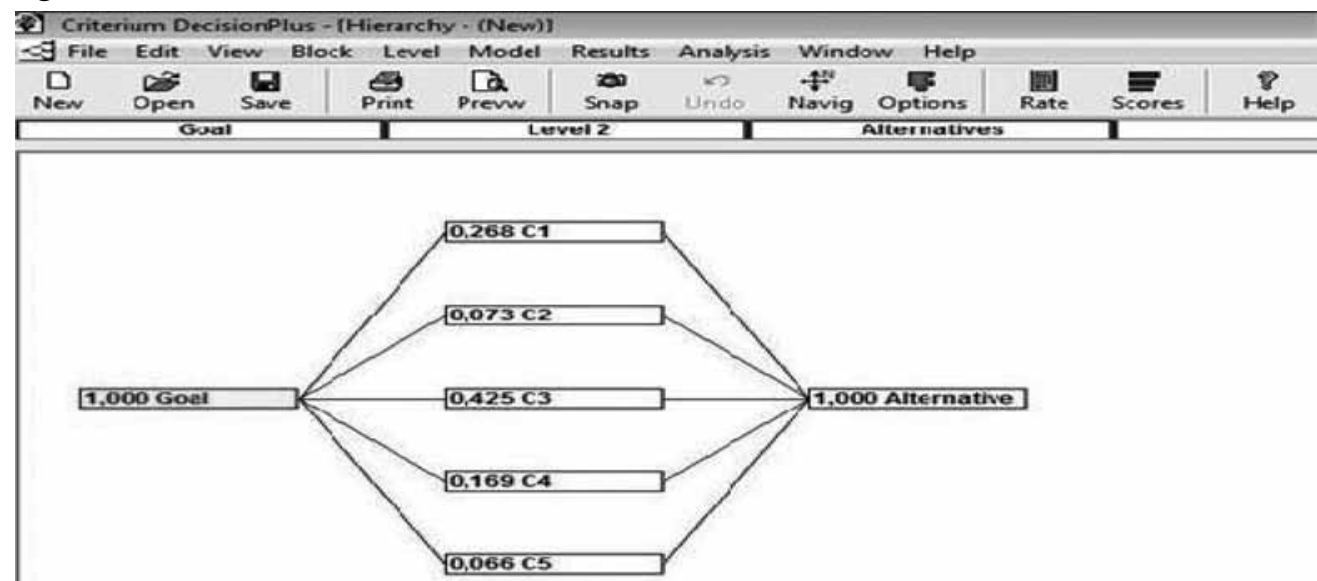

In order to rank the advantages of the mining companies, the authors have chosen the Electre method where it focuses on comparison the actions in pairs. The methodology of work is as follows: First, the degree of a agreement the paired connections and the weight of preferences are determined, and then the degree of disagreement is determined, where the assessments of weights of individual actions are mutually different. Differentiation of this method from the other MCDM methods is that the first has introduced the possibility of quantification in the problem of qualitative decision making.

The decision makers defined the problem, gave the appropriate alternatives (advantages) and defined the criteria that have a decisive influence on the decision making process. The starting point for these methods is the decision matrix and weight of criteria.

This method contains nine steps to solve the problem, to get the best alternative:

1. Calculation a normalized matrix of decision-making;

2. Creating a weight normalized matrix;

3. Resolving the sets of agreement and disagreement;

4. Calculation the matrix of agreement;

5. Calculation the matrix of disagreement;

6. Calculation the matrix of domination matrix by agreement,

7. Calculation the matrix of domination by disagreement,

8. Calculation the aggregate matrix of domination, and

9. Exclusion the worst alternatives. 
Methodology of work: the defined criteria evaluate the advantages (alternatives) of the mining companies and form the matrix of evaluation. Criteria due to the uncertain structure cannot be precisely determined; a qualitative scale is formed with the corresponding numerical values having five levels (Table 4).

Table 4. Qualitative scale of ELECTRE

\begin{tabular}{|c|c|c|c|c|c|}
\hline Qualitative values & Very poor & Poor & Medium & High & Very high \\
\hline Numerical values & 1 & 2 & 3 & 4 & 5 \\
\hline
\end{tabular}

In relation to the qualitative scale, in the range from 1 to 5 , a quantified decision matrix is calculated in the range from 1 to 5 (Table 5).

Table 5. Quantified decision matrix

\begin{tabular}{|c|c|c|c|c|c|}
\hline Alternatives/Criteria & C1 & C2 & C3 & C4 & C5 \\
\hline A1 & 4 & 3 & 4 & 3 & 5 \\
\hline A2 & 3 & 3 & 4 & 3 & 4 \\
\hline A3 & 4 & 4 & 5 & 4 & 5 \\
\hline A4 & 5 & 5 & 3 & 5 & 3 \\
\hline A5 & 5 & 4 & 5 & 5 & 4 \\
\hline
\end{tabular}

Based on this matrix, the calculation using the ELECTRE method uses its software.

I step: Calculation of the normalized matrix that is calculated by the formula:

$$
n_{i j}=\frac{c_{i j}}{\operatorname{Norma}_{j}}=\frac{C_{i j}}{\sqrt{\sum_{i=1}^{m} c_{i j}^{2}}}
$$

Based on the given data, this normalized decision matrix is obtained (Table 6). 
Table 6. Normalized decision matrix

\begin{tabular}{|c|c|c|c|c|c|}
\hline Alternatives/Criteria & C1 & C2 & C3 & C4 & C5 \\
\hline A1 & 0.41931 & 0.34641 & 0.41931 & 0.32733 & 0.52414 \\
\hline A2 & 0.31449 & 0.34641 & 0.41931 & 0.32733 & 0.41931 \\
\hline A3 & 0.41931 & 0.46188 & 0.52414 & 0.43644 & 0.52414 \\
\hline A4 & 0.52414 & 0.57735 & 0.31449 & 0.54554 & 0.31449 \\
\hline A5 & 0.52414 & 0.46188 & 0.52414 & 0.54554 & 0.41931 \\
\hline
\end{tabular}

II step: Calculation of the weight normalized matrix of decision making.

The decision maker, to choose one of the five alternatives (advantages), must show its preferences according to the attributes. Then, the weight-normalized decision matrix is calculated. The matrix of selected weight coefficients is:

$$
T N=N \cdot T
$$

Where,

$$
\mathrm{T}=\left[\begin{array}{ccc}
t_{1} & \cdots \cdots & 0 \\
\cdots & t_{2} \cdots & \cdots \\
\cdots & \cdots \cdots & \cdots \\
0 & \cdots \cdots & t_{n}
\end{array}\right]
$$

$\mathrm{N}$ denotes a normalized matrix. Total sum of the "diagonal" matrix of the given weights for the individual attributes (T) should be equal to the unit (1), i.e.

$$
\sum_{j=1}^{m} t_{1}=1
$$

The weight-normalized decision matrix is obtained by multiplying the matrix of selected weight coefficients and normalized matrix (Table 7).

Table 7. Weight normalized decision matrix

\begin{tabular}{|c|c|c|c|c|c|}
\hline & C1 & C2 & C3 & C4 & C5 \\
\hline A1 & 0.11238 & 0.02529 & 0.17821 & 0.05532 & 0.03407 \\
\hline A2 & 0.08428 & 0.02529 & 0.17821 & 0.05532 & 0.02726 \\
\hline A3 & 0.11238 & 0.03372 & 0.22276 & 0.07376 & 0.03407 \\
\hline A4 & 0.14047 & 0.04215 & 0.13366 & 0.09220 & 0.02044 \\
\hline A5 & 0.14047 & 0.03372 & 0.22276 & 0.09220 & 0.02726 \\
\hline
\end{tabular}


III step: Resolving the sets of agreement (S) and disagreement (NS).

A further methodology is the comparison of pairs in action that are marked with $\mathrm{p}$ and $\mathrm{r}(\mathrm{p}, \mathrm{r}=1,2, \ldots, \mathrm{m}$ and $\mathrm{p} \neq \mathrm{r})$. First, a set of agreement (spr) is formed for actions $a_{p}$ and $a_{r}$ consisting of defined criteria $(J=j$ and $j=1,2, \ldots, n)$, where the action $a_{p}$ is more desirable than the action $a_{r}$, i.e.

$$
s_{p r}=\left(j \mid x_{p j} \geq x_{r j}\right)
$$

If there is a minimum type criterion, the opposite is a sign of inequality $(\leq)$. Furthermore, a complementary set of disagreement is obtained, where:

$$
N S=\left(j \mid x_{p j}<x_{r j}\right)=J-S_{p r}
$$

If a minimum type criterion is obtained, the inequality sign is the opposite (>).

IV step: Calculation the matrix of agreeement (MS)

The matrix of agreeement is calculated in the previous step, and is calculated on the basis of the sets of agreement. The indexes of agreement are the matrix elements, calculated as the sum of preferences (weight coefficients).

The index of agreement $S_{p r}$ for actions $a_{p}$ and $a_{r}$ is calculated as follows:

$$
M S_{p r}=\sum_{j \in s_{p r}} t_{j}
$$

where its value ranges in the interval from 0 to 1 . So, the rule is applied, if the value of the given index is closer to the unit, the action $a_{p}$ is more desirable than the action $a_{r}$. In this way, the indexes of agreement form the matrix of agreement because it has the elements equal to zero on the main diagonal where the alternative does not compare with itself.

Presentation of the matrix of agreement is given in Table 8 .

Table 8. Consent matrix

\begin{tabular}{|c|c|c|c|c|c|}
\hline A1 & 0 & 1.00000 & 0.33300 & 0.49000 & 0.06500 \\
\hline A2 & 0.66700 & 0 & 0.00000 & 0.49000 & 0.06500 \\
\hline A3 & 1.00000 & 1.00000 & 0 & 0.49000 & 0.56300 \\
\hline A4 & 0.51000 & 0.51000 & 0.51000 & 0 & 0.51000 \\
\hline A5 & 0.93500 & 1.00000 & 0.93500 & 0.92700 & 0 \\
\hline
\end{tabular}


V step: Calculation the matrix of disagreement (MNS).

The indexes of disagreement constitute the elements of matrix of disagreement. They are calculated using the matrix TN (weight normalized matrix) in the following way:

$$
M N S_{p r}=\frac{\max _{j \in N P_{p r}}\left|t_{p j}-t_{r j}\right|}{\max \left|t_{\substack{p j \\ j \in J}}-t_{r j}\right|}
$$

And here, as in the previous step, the same rule is applied to the index of disagreement and determining a more desirable action. The index of disagreement is derived from the weight- normalized decision matrix (TN) and a set of disagreements for the observed alternatives (advantages) ( $\mathrm{NS}_{\mathrm{pr}}$ ).

The matrix of disagreement is shown in Table 9.

Table 9. Matrix of disagreement

\begin{tabular}{|c|c|c|c|c|c|}
\hline A1 & 0 & 0.00000 & 1.00000 & 0.82783 & 1.00000 \\
\hline A2 & 1.00000 & 0 & 1.00000 & 1.00000 & 1.00000 \\
\hline A3 & 0.00000 & 0.00000 & 0 & 0.31526 & 1.00000 \\
\hline A4 & 1.00000 & 0.79285 & 1.00000 & 0 & 1.00000 \\
\hline A5 & 0.15286 & 0.00000 & 0.24244 & 0.09461 & 0 \\
\hline
\end{tabular}

VI step: Calculation the matrix of agreement domination (MSD).

The matrix elements are calculated using the threshold of the agreement index, which are defined as the average index of agreement, and counted as:

$$
P I S=\sum_{\substack{p=1 \\ p \neq r}}^{m} \sum_{\substack{r=1 \\ p \neq r}}^{m} \frac{M S_{p r}}{m(m-1)}
$$

Based on calculation, a derived value of average index of agreement has shown that the action $\mathrm{a}_{\mathrm{p}}$ is preferable than the action $\mathrm{a}_{\mathrm{r}}$ and in case if its corresponding index of agreement $\mathrm{MS}_{\mathrm{pr}}$ exceeds the value of average index. The matrix of agreement domination is calculated on the basis of the following criterion:

$$
\begin{aligned}
& M S D_{p r}=1 \text { for } M S_{p r} \geq P I S \\
& M S D_{p r}=0 \text { for } M S_{p r}<P I S
\end{aligned}
$$


Matrix of agreement domination is shown in Table 10.

Table 10. Matrix of agreement domination

\begin{tabular}{|l|l|l|l|l|l|}
\hline $\mathrm{A} 1$ & 0 & 1 & 0 & 0 & 0 \\
\hline $\mathrm{A} 2$ & 1 & 0 & 0 & 0 & 0 \\
\hline $\mathrm{A} 3$ & 1 & 1 & 0 & 0 & 0 \\
\hline A4 & 0 & 0 & 0 & 0 & 0 \\
\hline A5 & 1 & 1 & 1 & 1 & 0 \\
\hline
\end{tabular}

VII step: Calculation the matrix of disagreement domination.

- As in the previous step, the matrix of disagreement domination is calculated in such a way that the average index of disagreement is first calculated through a relation:

$P I N S=\sum_{\substack{p=1 \\ p \neq r}}^{m} \sum_{\substack{r=1 \\ p \neq r}}^{m} \frac{M N S_{p r}}{m(m-1)}$

Table 11 shows the matrix of disagreement domination.

Table 11. Matrix of disagreement domination

\begin{tabular}{|l|l|l|l|l|l|}
\hline A1 & 0 & 1 & 0 & 0 & 0 \\
\hline A2 & 0 & 0 & 0 & 0 & 0 \\
\hline A3 & 1 & 1 & 0 & 1 & 0 \\
\hline A4 & 0 & 0 & 0 & 0 & 0 \\
\hline A5 & 1 & 1 & 1 & 1 & 0 \\
\hline
\end{tabular}

VIII step: Calculation the matrix of aggregate domination (MAD).

Matrix of aggregate domination is calculated as a product of position the elements of matrix of agreement and matrix of disagreement domination:

$$
M A D_{p r}=M S D p r \cdot M N S D p r
$$

Calculation of the aggregate domination matrix is shown in Table12. 
Table 12. Matrixes of aggregate domination

\begin{tabular}{|c|c|c|c|c|}
\hline $\mathrm{A} 1$ & 1 & 0 & 0 & 0 \\
\hline 0 & $\mathrm{~A} 2$ & 0 & 0 & 0 \\
\hline 1 & 1 & $\mathrm{~A} 3$ & 0 & 0 \\
\hline 0 & 0 & 0 & $\mathrm{~A} 4$ & 0 \\
\hline 1 & 1 & 1 & 1 & $\mathrm{~A} 5$ \\
\hline
\end{tabular}

IX step: Exclusion of less desirable actions.

If the value is $M A D_{p r}=1$, then the action $a_{p}$ dominates over the action $a_{r}$ by one and the other criterion (agreement and disagreement). This does not show that there is no other alternative that does not dominate over the action $\mathrm{a}_{\mathrm{p}}$. Therefore, one more condition has to be met:

$\mathrm{MAD}_{\mathrm{pr}}=1$ for at least one $\mathrm{r}, \mathrm{r}=1,2, \ldots, \mathrm{m}$ and $\mathrm{p} \neq \mathrm{r}$

$\mathrm{MAD}_{\mathrm{pr}}=0$ for all $\mathrm{i}, \mathrm{i}=1,2, \ldots, \mathrm{m}$ i $\quad \mathrm{p} \neq \mathrm{r}$ and $\mathrm{i} \neq \mathrm{r}$

The results of implementation combined by the AHP and Electre methods show that:

- A1 dominates over: A 2

- A2 does not dominate over any action

- A3 dominates over: A 1 and A2

- A4 does not dominate over any action

- A5 dominates over: A1, A2 and A4

- The best alternative: A5

\section{Results and Discussion}

The results of the integrated method, AHP and Electre show that the best alternative is A5, implementation of the Integrated Management System (ISM). Implementation the ISM helps to the managers of the mining companies to manage the changes integrally in a standardized and easier way. Change management is the hardest task of the professional managers. The implemented method provides the opportunity to the mining companies to function according to the ISO standards where they are more competitive and able to manage the changes.

The alternative A3, staff competence, is in the second place. The mining companies require, due to their complexity, the competent staff to plan, organize, control, and manage processes in a changeable environment. Staff competence is the basic element of the mining companies prescribed in the QMS management standards. On the basis of this, it is seen that the staff competence gives managers the ability to manage effectively the changes 
The ranked advantages of the mining companies, as well as the ability to manage the changes by the multi-criterial analysis, combined AHP and Electre method, is obtained that the teamwork, alternative A1, is at the third place. Today's changeable business requires the mining companies to make the team decisions strategically bringing the ability to manage the resulting changes.

The knowledge management and equipment are very important as the benefits for the ability to manage the change in the mining companies. Without knowledge, there is no recognition and analysis of the available and necessary resources and work processes. In the case of alternative equipment, if the mining companies are not equipped according to the needs of the process and demands of the interested parties, there is no conquest of the new markets nor survival of the company.

Regarding the criteria, the most influential criterion for ranking the advantages of the mining companies is the criterion $\mathrm{C} 3$, the satisfaction of the interested parties, because its weight coefficient is 0.425 . It means that this criterion affects with $42.5 \%$ of the mining company benefits. Organizations exist for the users and consumers that form an integrated group with the other interested parties. The ISO 9001: 2015 under item 4, the context of an organization, requires understanding and needs of expectation of the interested parties.The interested parties are the groups of people who are interested in achieving the organizational goals, all for the sake of profit.

At the second place, by influence the ranking of advantages in the mining companies, is the criterion $\mathrm{Cl}$, competitiveness because its weight coefficient is 0.268 ; what means that it affects with $26.8 \%$ to the final result. Without competition as the basis of economic science, there is no survival for the mining companies. Being competitive is an increase in the satisfaction of the needs and demands of the interested parties.

At the third place is the criterion $\mathrm{C} 4$, positioning with weight coefficient of 0.169 ; which means that with $16.9 \%$ it affects the ranking of advantages of the mining companies and making the final decision making. Good positioning determines the place of the mining companies on the market compared to the competition.

At the fourth place is the criterion $\mathrm{C} 42$, sustainability, because its weight coefficient is 0.073 . This criterion affects $7.3 \%$ to the final result of ranking the benefits. The sustainable business of the mining companies is considered to be a dynamic and continuous process that requires a great adaptation and flexibility (Miletić et al., 2016c).

At the fifth, and the last place, is the criterion $\mathrm{C} 5$, the resistances of employees because their weight coefficient is 0.066 . The final result is influenced by $6.6 \%$. Resistance as a criterion is important for ranking the preferences of the mining companies because they are very common in today's business due to the 
major changes. The professional managers have this role to reduce the employee resistances and motivate them.

\section{Conclusion}

This work presents the original methodology of multicriterial analysis advantages of the mining companies as the ability to manage the changes. The five most significant advantages in the mining companies, teamwork, knowledge management, staff competence, equipment and implementation of the integrated management system (ISM) are analyzed. The used criteria were: competitiveness, sustainability, the satisfaction of interested parties, and positioning with which they were prioritized. Such a multiple analysis requires the application of an appropriate MCDM method. In the first stage of realization for determining the criteria and their weight coefficients, the AHP method was used due to the subjectivity of a decision making. In the second phase of implementation for ranking the alternatives (priority), the Electra method was used due to quantification in the problem of qualitative decision making.

The main result of this work is a comparative analysis of the results, obtained by combining the AHP and Electra method.

The best alternative (advantages) for the mining companies is the alternative A5, implementation of the Integrated Management System (ISM).

The most influential criterion for the final ranking is the criterion $\mathrm{C} 3$, the satisfaction of the interested parties.

The applied methodology provides a great opportunity and ability to the professional managers to manage the changes in today's business with the mining companies. Such combined methods can be used to solve other conflicting problems in the process of managing the mining companies by other combined methods.

The proposed model, compared to the results of other models, can be modified so that different decision makers have a different impact on the weight of the criteria, which also influences the choice of the most acceptable alternative.

The authors propose further research in the process of adopting and solving the conflict problems in the process of managing the mining companies with the other combined methods. 


\section{Literature}

- Bogdanović, D., \& Miletić, S. (2014): Personnel evaluation and selection by multicriteria decision making method, Journal of Economic Computation and Economic Cybernetics Studies and Research, 48(3)/2014, 179-196.

- Bogdanović, D. (2016): Upravljanje promenama, Tehnički fakultet u Boru, Univerzitet u Beogradu.

- Certo, S. (1988): Principles of Modern Managemenat, Allin and Bacon, Bostan.

- Chauvin, B., Rohmer, O., Spitzenstetter, F., Raffin, D., Schimchowitsch, S., Louvet, E. (2014): Assessment of job stress in factors in context of organizational change, Elsevier Masson SAS.

- Daft, R.L. (2001): Organization Theory and Desing, Seventh Edition, South West Publishing, Tomson Learing, Vanderbilt University.

- Demsetz, H. (1982): Economic, Legal, and Political Dimensions of Competition, NorthHolland, Amsterdam.

- Hayesu, J. (2002): The Theory and Practice of Change Management, New York.

- Hillier, F., \& Lieberman, G. (2001): Introduction to Operations Research, New York: McGraw-Hill.

- Hylton, A. (2002): Measuring \& Assessing Knowledge-Value \& the Pivotal Role of the Knowledge Audit, CEO, Hylton Associates.

- Jovanović, P. (1996): Management-Handbook of managemet, FON, Beograd.

- Kangas J. (2011): Experiences on applying MCDM tools in natural resources management, The 21st International Conference on Multiple.

- Karabasevic, D., Stanujkic, D., Urosevic, S. \& Maksimovic, M. (2015): Selection of Candidates in the Mining Industry Based on the Application of the SWARA and the MULTIMOORA Methods, Acta Montanistica Slovaca, $20(2) / 2015,116-124$.

- Karabasevic, D., Zavadskas, E. K., Turskis, Z., Stanujkic, D. (2016): The framework for the selection of personnel based on the SWARA and ARAS methods under uncertainties, Informatica, 27(1)/2016, 49-65.

- $\quad$ Lee, W.B., Lau, H., Liu, Z.Z., Tam, S. (2001): A fuzzy analytical hierarchy process approach in modular product design, Expert System, 18(1)/2001, $32-42$.

- Lee, C., Egbu, C., Boyd, D., Xiao, H., \& Chinyo, E. (2005): Knowledge Management for Small Medium Enterprise: Capturing and Communicating Learning and Experiences, 4th Triennial International Conference Rethinking and Revitalizing Construction Safety, Health, Environment and Quality, 808-20.

- Mazur, M., Spahić, A., Grabar, D., Grd, P.,Sedlbauer, G.,Siroska, K., Pallares Beamonte, E. (2014): Knowledge Management 2.0 for SMEs, km20.eu. 
- Miletić S., Bogdanović, D., Paunković, Dž.(2015): Selection the optimal model of integrated sustainable management system in the mining companies, Journal Mining and Metallurgy Engineering Bor, 2/2015, 181-204.

- Miletić, S., Bogdanović. D., Milanović, D. (2016): Advantages of implementation the process model for sustainable business operations of mining companies, Journal Mining and Metallurgy Institute Bor, 3/2016, 71-82.

- Miletić, S., Bogdanović, D., Paunković, Dž., Mihajlović, D.(2016): Primena višekriterijumskog odlučivamja u cilju procene održivog poslovanja rudraskih kompanija, Reciklaža i održivi razvoj, 9/2016, 15-20.

- Miletić, S., Paunković, Dž., Mihajlović, D., Bogdanović, D., Đurić, M. (2016): Ilustracija modela održivog poslovanja rudarskih kompanija, Ekologica, 23(82)/2016, 360-365.

- Miletić, S., Paunković, Dž., Bogdanović, D., (2016). Evaluacija indikatora održivosti za donošenje odluka u rudarskim kompanijama. Megatrend revija, 13(2)/2016, 83-96.

- Roy, B. (1991): The outranking approach and the foundation of electre methods, Theory Decision 31, 49-73.

- Saaty, T.L. (1980): The Analytical Hierarchy Process, New York: McGrawHill.

- Sveiby, K.E. (1996): What is Knowledge Management? Criteria Decision Making, University of Jyvaskyla, Finland.

- Stanujkić, D. (2015): Extension of the ARAS Method for Decision-Making Problems with Interval-Valued Triangular Fuzzy Numbers, Informatica, 26(2)/2015, 335-355.

- Stanujkić, D. (2016): An Extension of the Ratio System Approach of Moora Method for Group Decision-Making Based on Interval-Valued Triangular Fuzzy Number, Technological and Economic Development of Economy, 22(1)/2016, 122-141.

- Sullivan, K., Thomas, S., Rosano, M. ( 2018): Using industrial ecology and strategic management concepts to pursue the Sustainable Development Goals, Journal of Cleaner Production, 174/218, 237-246.

- Urošević, S., Karabašević, D., Stanujkić; D., Maksimović, M. (2017): An approach to personnel selection in the tourism industry based on the swara and the waspas methods, Economic Computation \& Economic Cybernetics Studies \& Research, 51(1)/2017 75-88.

- Vincke, P. (1992): Multicriteria Decision - Aid, Chichester: John Wiley \& Sons.

- Zavadskas, E.K., Turskis, Z., Kildienè, S. (2014): State Of Art Surveys Of Overviews On MCDM/MADM Methods, Technologcal and Economic Development of Economy, 20(1)/2014, 165-179. 
- Zavadskas, E. K., Antucheviciene, J., Saparauskas, J., Turskis, Z. (2013): MCDM methods WASPAS and MULTIMOORA: verification of robustness of methods when assessing alternative solutions, Economic Computation and Economic Cybernetics Studies and Research, 47(2)/2013, 5-20.

- Żak, J., \& Kruszyńskib, M. (2015): Application of AHP and ELECTRE III/IV methods to multiple level, multiple criteria evaluation of urban transportation projects, Transportation Research Procedia, 10/2015, 820 - 830.

\section{APPENDIX}
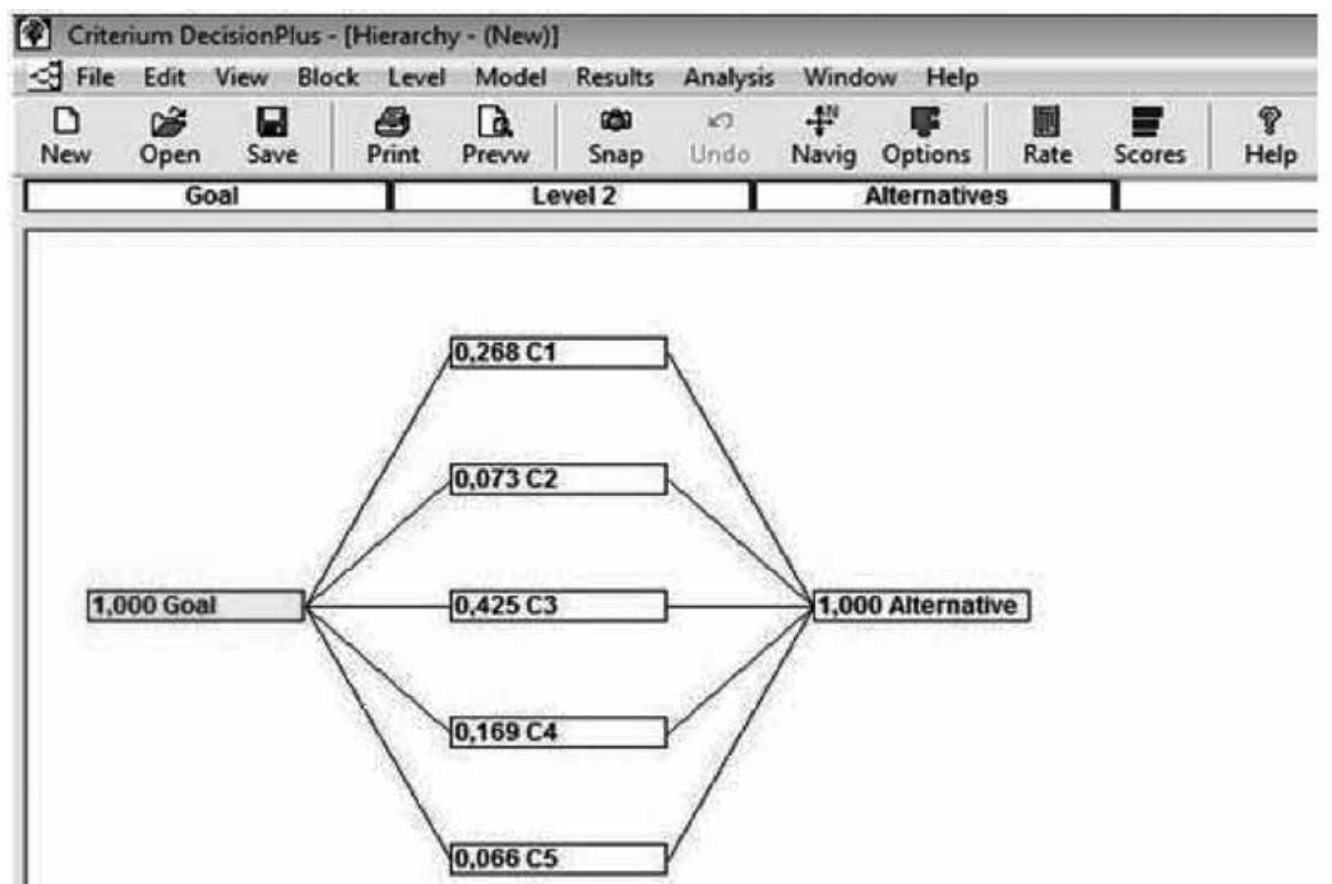

Figure 1. Hierarchical structure 


\section{MULTIKRITERIJUMSKA ANALIZA PREDNOSTI RUDARSKIH KOMPANIJA SA ASPEKTA UPRAVLJANJA PROMENAMA}

Cilj rada je evaluacija prednosti rudarske kompanije multikriterijumskom analizom. Ovakav pristup rudarskim kompanijama predstavlja najbolju praksu jer je usled globalnih promena sve veći broj kompanija koje je prinuđeno da istakne svoje prednosti radi očuvanja i ekspanzije tržišnih pozicija, profita i uspešno upravljanje promenama.

$U$ radu su analizirane pet prednosti (alternative): timski rad, upravljanje znanjem, kopetentnost osoblja, opremljenost $i$ implementacija integrisanog sistema menadžmenta (ISM) i četiri kriterijuma: konkurentnost, održivost, zadovoljstvo zainteresovanih strana i poziciranje. Analiza je uradena kombinovanom AHP i Electre metode.

Prikazana multikriterijumska analiza je dala sledeće rezultate: njabolja altenativa je alternativa A5, implementacija ISM a najuticajniji kriterijum je C3, zadovoljstvo zainteresovanih strana sa težinskim koeficijentom 0,425.

Ključne reči: Multikritrijumska analiza, Rudarske kompanije, Upravljanje promenama 